\title{
Effects of container types and soil organic matter proportions on the culture of a tropical earthworm (Libyodrilus violaceus Beddard, 1891)
}

\author{
E. O. Dada ${ }^{1, ~}$, K. L. Njoku ${ }^{1}$, A. A. Osuntoki ${ }^{2}$, M. O. Akinola ${ }^{1,3}$ \\ ${ }^{1}$ Department of Cell Biology and Genetics, University of Lagos, Lagos, Nigeria \\ ${ }^{2}$ Department of Biochemistry, University of Lagos, Lagos, Nigeria \\ ${ }^{3}$ Department of Environmental Science, University of Botswana, Gaborone, Botswana
}

\section{Email address:}

eodada1@yahoo.com(E. O. Dada)

\section{To cite this article:}

E. O. Dada, K. L. Njoku, A. A. Osuntoki, M. O. Akinola. Effects of Container Types and Soil Organic Matter Proportions on the Culture of a Tropical Earthworm (Libyodrilus violaceus Beddard, 1891). American Journal of Life Sciences. Vol. 1, No. 4, 2013, pp. $150-154$. doi: 10.11648/j.ajls.20130104.12

\begin{abstract}
Earthworms are becoming increasingly useful in solving human and environmental problems. In addition to biomonitoring and soil fertility renewing roles, they are now used as livestock feed, therapeutic agents and soil contaminants remover. It is therefore imperative to encourage more earthworm culture research. The aim of this study was to determine the extent to which container types and soil amendments affect the breeding of Libyodrilus violaceus Beddard, 1891 in the laboratory. The earthworm species was cultured in loamy sandy soil amended with different proportions of cow dung inside earthenware, plastic and wooden pots for a period of twelve weeks in the laboratory. The data generated were subjected to multivariate analysis of variance (MANOVA) using the general linear model (GLM) multivariate tests. These tests indicated that both pot and soil types had significant influence on $L$. violaceus culture. The effects of pot type was more significant $($ Lambda $=0.114, \mathrm{p}<0.001)$ compared to soil type $($ Lambda $=0.302, \mathrm{p}<0.001)$. Follow-up univariate analysis of variance indicated that pot type had more significant influence on final earthworm number $(\mathrm{F}=68.74, \mathrm{p}<0.001)$ than the final weight $(\mathrm{F}=7.14, \mathrm{p}<0.005)$. While soil type had a strong significant influence on the final number of earthworms $(\mathrm{F}=12.24, \mathrm{p}<0.001)$, its influence on the final weight was not significant $(\mathrm{F}=2.20, \mathrm{p}>0.05)$. Wooden pot had the highest mean final earthworm number $(76.50 \pm 20.27)$, followed by earthenware pot $(61.75 \pm 16.43)$. Loamy soil amended with $25 \%$ cow dung had the highest mean final earthworm number in the three types of pot, $82.67 \pm 11.93,32.00$ \pm 7.00 , and $94.00 \pm 11.53$ for earthenware, plastic and wooden pots respectively. These findings imply that if $L$. violaceus must be cultured ex situ, wooden pot should be preferred above earthenware and plastic, while loamy soil amended with $25 \%$ cow dung should be preferred over other soil amendments.
\end{abstract}

Keywords: Cow Dung, Pot Types, Soil Types, Vermiculture

\section{Introduction}

The current unfolding knowledge and discoveries of potential uses of earthworms make it imperative to focus more attention on vermiculture research. Earthworms enhance total plant growth and crop productivity. They renew soil fertility by continuously burrowing, ingesting, turning, mixing, aerating, and improving the drainage of soil. They can increase soil fertility and plant growth by between 30 and $200 \%$ [1, 2]. Earthworms have been successfully introduced into reclaimed soils to restore soil fertility [3]. Earthworms have been identified as good biomonitoring agents $[4,5,6,7]$. They can be used to clean up contaminants [2]. They can also be used to convert municipal wastes to vermicompost $[8,9]$. Research efforts have confirmed the efficacies of earthworm powder, earthworm extract, and earthworm protease in preventing and healing diseases such as myocardial infarction, cancer, ulcer, diabetes $[2,10,11,12]$. Earthworms are widely used as aqua and livestock feed [13]. If these potential benefits of earthworms are to be fully and sustainably tapped into, then there is the need to raise more earthworms both in situ and ex situ in order to match supply with demand. Moreover, earthworm availability from natural habitat is seasonal [14] for most species. 
Different earthworm species have been reared ex situ in various soil amendments and other media [14, 15, 16, 17]. Libyodrilus violaceus is an endogeic wetland earthworm species native to West Africa. It makes a major contribution to the productivity of many river basin agricultural projects in Nigeria [1]. The aim of this research was to determine the extent to which pot types and soil cow dung amendments affect the breeding of $L$. violaceus in the laboratory.

\section{Materials and Method}

\subsection{Sample Collection Site}

Soil and earthworm samples were collected at the back of Medical Centre of the main campus of the University of Lagos, Nigeria. The University is located on longitude $3^{\circ}$ $24^{\prime} \mathrm{E}$ and latitude $6^{\circ} 27^{\prime} \mathrm{N}$ within the Mainland of Lagos, Nigeria.

\subsection{Collection and Identification of Earthworm}

Libyodrilus violaceus were collected by digging with a shovel to an average depth of $22 \mathrm{~cm}$ and hand sorting. The collection was limited to a particular area to reduce variability [18]. The species was identified as in [7].

\subsection{Collection of Soil}

Loamy sandy soil used for this study was collected at 0 $2.00 \mathrm{~cm}$ depth, bulked together, air dried, and passed through a $2 \mathrm{~mm}$ sieve. A portion of the bulked soil was taken to the laboratory for baseline physico-chemical analysis (Table 1).

Table 1. Physico-chemical properties of test soil

\begin{tabular}{ccccccccccccc}
\hline o/o & o/o & o/o & o/o & o/o & \multicolumn{9}{c}{ Metals(mg/kg) } & & CEC (meg/100g) \\
\hline sand & silt & clay & ToC & moisture & $\mathrm{pH}$ & $\mathrm{Zn}$ & $\mathrm{Pb}$ & $\mathrm{Cd}$ & $\mathrm{Na}+$ & $\mathrm{K}+$ & $\mathrm{Mg} 2+$ & $\mathrm{Ca} 2+$ \\
69 & 14 & 14 & 2.78 & 7.59 & 6.90 & 2.94 & 0.24 & $\mathrm{ND}$ & 5.87 & 4.07 & 8.17 & 14.71 \\
\hline
\end{tabular}

ToC $=$ total organic carbon $\quad \mathrm{ND}=$ not detected $\quad \mathrm{CEC}=$ cation exchange capacity

\subsection{Collection and Preparation of Cowdung}

The cow dung used for the study was collected from a remote nomadic cattle rearers settlement in Kwara State, Nigeria. The cow dung was dry to touch at the time of collection. Approximately $25 \mathrm{~kg}$ of the dry cow dung was separately weighed into four plastic containers. To each of these containers was added 7,500 $\mathrm{ml}$ of tap water that has been left in the open for more than 24 hours to allow the chlorine content escape. The mixture was left to stand for 14 days to completely eliminate the risk of excessive heat that might be generated from fermentation. At the end of the 14 days, the mixture was thoroughly mixed together resulting in a semi-solid paste.

\subsection{Breeding Procedure}

The experiment was carried out in three groups earthenware pot [17], plastic pot [19] and wooden pot [14]. Each of these groups was again divided into 4 sub-groups. The first was the control (1) having loamy soil only. The remaining three sub-groups $(2,3$, and 4$)$ were amended with cow dung in different proportions of cow dung to soil ratios as follows: 10:90, 25:75, 50:50 respectively. Hence, there were twelve groups. Each of these was replicated three times.

The appropriate quantities of soil were put in each pot and appropriate volumes of water were added to make $30 \%$ water in case, and left to stand for 3 days. Twenty fully clitellate adult $L$. violaceus were weighed, put into each pot, and allowed to burrow. After burrowing, the right quantity of cow dung was added to each pot to make the required proportion of cow dung to soil ratio. A thin layer of soil (1 $\mathrm{cm})$ was spread on top of the cow dung [17]. Each pot contained approximately $10,000 \mathrm{~g}$ of soil and cow dung mixture. The pots were covered with a $2 \mathrm{~mm}$ net. Exactly $750 \mathrm{ml}$ of water was sprinkled in each pot every 3 days [17]. The breeding experiment lasted twelve weeks. The weight of the earthworms was taken before and after the experiment to determine the weight difference in each pot. Similarly, the difference between the initial and final earthworm number was taken to determine the breeding rate of worms in each pot.

\subsection{Analysis of Data}

All data collected were subjected to multivariate analysis of variance (MANOVA) using the general linear model (GLM) multivariate analysis. Post hoc test was carried out using least significance differences (LSD). Difference in mean was considered significant at $\mathrm{P}<0.05$, among the variables. Pillai's trace, Wilks' Lambda, Hotelling's trace, and Roy's largest root tests were used to determine the overall effects of soil and pot types on the culture of $L$. violaceus. All analyses were carried out with the Statistical Package for Social Science software, (SPSS 17.0).

\section{Results}

Table 2 presents the descriptive statistic for the initial and final number of $L$. violaceus. The offsprings produced by the parent earthworms (initial worms) still remained juveniles at the end of the experiment. The mean final number of $L$. violaceus for each pot type (earthenware, plastic and wooden) was significantly higher than the initial number $(\mathrm{p}<0.05)$. However, wooden pot had the highest mean value $(76.50 \pm 20.27)$, followed by earthenware $(61.75 \pm 16.43)$ and plastic $(29.42 \pm 5.04)$. Loamy soil 
amended with 25\% cow dung had the highest and significant final number mean values of $82.67 \pm 11.93$, $32.00 \pm 7.00$, and $94.00 \pm 11.53$ for earthenware, plastic, and wooden pots respectively. This was followed by the soil amended with $50 \%$ cow dung with final mean values of
$65.00 \pm 7.94,28.67 \pm 2.52$, and $89.67 \pm 17.62$ for earthenware, plastic, and wooden pots respectively. The mean values for loamy soil amended with $10 \%$ cow dung were not significant when compared with the control.

Table 2. Descriptive statistic for the initial and final number of L. violaceus

\begin{tabular}{|c|c|c|c|c|c|c|}
\hline Type of Pot & Type of soil & $\begin{array}{c}\text { Initial } \\
\text { no }\end{array}$ & $\begin{array}{c}\text { Final } \\
\text { total no }\end{array}$ & $\begin{array}{l}\text { Increase } \\
\text { in worms }\end{array}$ & $\begin{array}{c}\% \\
\text { increase }\end{array}$ & $\begin{array}{l}\text { Mean total } \\
\quad+\text { SD }\end{array}$ \\
\hline \multirow{5}{*}{ Earthenware } & Loamy (control) & 60 & 132 & 72 & 120.00 & $44.00 \pm 5.56$ \\
\hline & Amended(10:90) & 60 & 166 & 106 & 176.67 & $55.33 \pm 6.50$ \\
\hline & Amended(25: 75) & 60 & 248 & 188 & 313.33 & $82.67 \pm 11.93 *$ \\
\hline & Amended(50:50) & 60 & 195 & 135 & 225.00 & $65.00 \pm 7.94^{*}$ \\
\hline & Total & 240 & 740 & 500 & 208.33 & $61.75 \pm 16.43 a$ \\
\hline \multirow{5}{*}{ Plastic } & Loamy (control) & 60 & 81 & 21 & 35.00 & $27.00 \pm 4.00$ \\
\hline & Amended(10:90) & 60 & 90 & 30 & 50.00 & $30.00 \pm 7.00$ \\
\hline & Amended(25:75) & 60 & 86 & 26 & 43.33 & $32.00 \pm 7.00^{*}$ \\
\hline & Amended(50:50) & 60 & 86 & 26 & 43.33 & $28.67 \pm 2.52 *$ \\
\hline & Total & 240 & 343 & 103 & 42.92 & $29.42 \pm 5.04 \mathrm{a}$ \\
\hline \multirow{5}{*}{ Wooden } & Loamy (control) & 60 & 176 & 116 & 193.33 & $58.67 \pm 12.66$ \\
\hline & Amended(10:90) & 60 & 191 & 131 & 218.33 & $63.67 \pm 14.57$ \\
\hline & Amended(25:75) & 60 & 282 & 222 & 370.00 & $94.00 \pm 11.53^{*}$ \\
\hline & Amended(50:50) & 60 & 269 & 209 & 348.33 & $89.67 \pm 17.62 *$ \\
\hline & Total & 240 & 918 & 678 & 282.50 & $76.50 \pm 20.27^{\mathrm{a}}$ \\
\hline
\end{tabular}

*Mean difference for soil type is significant at $\mathrm{p}<0.05$ when compared with the control

${ }^{\mathrm{a}}$ Mean difference for pot type is significant at $\mathrm{p}<0.05$ for pairwise comparison (LSD)

The descriptive statistic for the initial and final weights of L. violaceus is presented in Table 3. Only wooden pot had a significant mean value $(19.22 \pm 1.35)$ for final weight of L. violaceus. Morever, only loamy soil amended with $25 \%$ respectively. cow dung had significant effect on final weight of $L$. violaceus, with mean values of $19.84 \pm 1.73,17.94 \pm 0.64$, and $19.63 \pm 1.38$ for earthenware, plastic, and wooden pots

Table 3. Descriptive statistic for the initial and final weights of L. violaceus

\begin{tabular}{|c|c|c|c|c|c|c|c|}
\hline Type of pot & Type of soil & $\begin{array}{c}\text { Initial } \\
\text { no }\end{array}$ & $\begin{array}{c}\text { Initial } \\
\text { wt(g) }\end{array}$ & $\begin{array}{l}\text { Final } \\
\text { wt(g) }\end{array}$ & $\begin{array}{l}\text { Increase } \\
\text { in wt(g) }\end{array}$ & $\begin{array}{c}\text { o/o wt } \\
\text { increase }\end{array}$ & Mean + SD \\
\hline \multirow{5}{*}{ Earthenware } & Loamy(control) & 60 & 47.98 & 50.91 & 2.93 & 6.11 & $16.97 \pm 0.49$ \\
\hline & Amended(10:90) & 60 & 48.40 & 55.93 & 7.53 & 15.56 & $18.34 \pm 0.67$ \\
\hline & Amended(25:75) & 60 & 48.65 & 59.52 & 10.87 & 22.34 & $19.84 \pm 1.73 *$ \\
\hline & Amended(50:50) & 60 & 48.20 & 54.35 & 6.15 & 12.75 & $18.11 \pm 0.93$ \\
\hline & Total & 240 & 193.23 & 220.71 & 27.48 & 14.22 & $18.32 \pm 1.40$ \\
\hline \multirow{5}{*}{ Plastic } & Loamy(control) & 60 & 48.52 & 53.54 & 5.02 & 10.34 & $17.80 \pm 0.72$ \\
\hline & Amended(10:90) & 60 & 48.34 & 51.60 & 3.00 & 6.21 & $17.20 \pm 0.28$ \\
\hline & Amended(25:75) & 60 & 48.52 & 53.81 & 5.29 & 10.90 & $17.94 \pm 0.64 *$ \\
\hline & Amended(50:50) & 60 & 48.11 & 51.02 & 2.91 & 6.05 & $17.01 \pm 0.10$ \\
\hline & Total & 240 & 193.49 & 209.82 & 16.33 & 8.44 & $17.48 \pm 0.59$ \\
\hline \multirow{5}{*}{ Wooden } & Loamy(control) & 60 & 48.31 & 56.40 & 8.09 & 16.75 & $18.80 \pm 0.36$ \\
\hline & Amended(10:90) & 60 & 48.31 & 57.40 & 9.09 & 18.81 & $19.13 \pm 1.92$ \\
\hline & Amended( $25: 75)$ & 60 & 48.40 & 58.90 & 10.50 & 21.69 & $19.63 \pm 1.38^{*}$ \\
\hline & Amended(50:50) & 60 & 48.40 & 57.90 & 9.50 & 19.63 & $19.30 \pm 1.95$ \\
\hline & Total & 240 & 193.42 & 230.60 & 37.18 & 19.22 & $19.22 \pm 1.35 a$ \\
\hline
\end{tabular}

${ }^{*}$ Mean difference for soil type is significant at $\mathrm{p}<0.05$ when compared with the control (LSD)

${ }^{\mathrm{a}}$ Mean difference for pot type is significant at $\mathrm{p}<0.05$ for pairwise comparison (LSD)

The multivariate tests of significance for the overall effects of pot type and soil type on the culture of $L$. violaceus is presented in Table 4. For the effect of pot type, the values of these tests are 0.909 (Pillai's trace), 0.114 (Wilks' Lambda), 7.612 (Hotelling's trace) and 7.586 (Roy's largest root). The corresponding values for soil type are $0.734,0.302,2.193$ and 2.137 respectively. The values for the type of pot and type of soil interaction effect are $0.589,0.457,1.089$, and 0.979 for Pillai's trace, Wilks'
Lambda, Hotelling's trace and Roy's largest root respectively.

The univariate analysis of variance of effects of pot and soil types on the final number and final weight of $L$. violaceus in the experiment is presented in Table 5. Pot type produced strong significant effects on both the final total number $(\mathrm{F}=68.74, \mathrm{p}<0.001)$ and weight $(\mathrm{F}=7.14, \mathrm{p}$ $<0.005)$ of $L$. violaceus. The effects of soil type on the final total number of $L$. violaceus was significant $(\mathrm{F}=$ 
$12.24, \mathrm{p}<0.001)$ but was not significant on the final weight $(\mathrm{F}=2.20, \mathrm{p}>0.05)$. The interaction of pot and soil types not significant $(\mathrm{F}=0.95, \mathrm{p}>0.05)$. has a low significant value $(\mathrm{F}=2.67, \mathrm{p}<05)$ for the final number of $L$. violaceus but the effect for final weight was

Table 4. GLM multivariate tests of significance of effects of pot type and soil type on the culture of Libyodrilus violaceus

\begin{tabular}{|c|c|c|c|c|c|}
\hline \multirow{2}{*}{ Effect } & & \multirow{2}{*}{ Value } & \multicolumn{2}{|c|}{ Degree of freedom (df) } & \multirow{2}{*}{ Sig } \\
\hline & & & Hypothesis & Error & \\
\hline \multirow{4}{*}{ Pot type } & Pillai's Trace & 0.909 & 4.000 & 48.000 & $<0.001$ \\
\hline & Wilks' Lambda & 0.114 & 4.000 & 46.000 & $<0.001$ \\
\hline & Hotelling's Trace & 7.612 & 4.000 & 44.000 & $<0.001$ \\
\hline & Roy's Largest Root & 7.586 & 2.000 & 24.000 & $<0.001$ \\
\hline \multirow{4}{*}{ Soil Type } & Pillai's Trace & 0.734 & 6.000 & 48.000 & 0.001 \\
\hline & Wilks' Lambda & 0.302 & 6.000 & 46.000 & $<0.001$ \\
\hline & Hotelling's Trace & 2.193 & 6.000 & 44.000 & $<0.001$ \\
\hline & Roy's Largest Root & 2.137 & 3.000 & 24.000 & $<0.001$ \\
\hline \multirow{4}{*}{ Type of pot*Soil Type } & Pillai's Trace & 0.589 & 12.000 & 48.000 & 0.104 \\
\hline & Wilks' Lambda & 0.457 & 12.000 & 46.000 & 0.070 \\
\hline & Hotelling's Trace & 1.084 & 12.000 & 44.000 & 0.049 \\
\hline & Roy's Largest Root & 0.979 & 6.000 & 24.000 & 0.007 \\
\hline
\end{tabular}

Data considered significantly different at $\mathrm{p}<0.05$

Table 5. Univariate analysis of variance of effects of pot types and soil types on the final number and weight of Libyodrilus violaceus

\begin{tabular}{|c|c|c|c|c|}
\hline Source & Dependent variable & df & $\mathbf{F}$ & Sig \\
\hline \multirow{2}{*}{ Type of Pot } & Final total no & 2 & 68.738 & $<0.001$ \\
\hline & Final weight of worms & 2 & 7.139 & 0.004 \\
\hline \multirow{2}{*}{ Soil type } & Final total no & 3 & 12.243 & $<0.001$ \\
\hline & Final weight of worm & 3 & 2.195 & 0.115 \\
\hline \multirow{2}{*}{ Type of pot*Soil type } & Final total no & 6 & 2.669 & 0.040 \\
\hline & Final weight of worms & 6 & 0.947 & 0.481 \\
\hline
\end{tabular}

Data considered significantly different at $\mathrm{p}<0.05$

\section{Discussion}

The high and positive values of Pillai's trace (0.909), Hotelling's trace (7.612), Roy's largest root (7.586); and the low positive value of Wilks' Lambda (0.114) for pot type are all a pointer to the strong influence of pot type on the breeding of $L$. violaceus. The same pattern of values observed for soil type also indicates the strong influence of soil type on the breeding of this species. However, it was observed that the difference between the values of Hotelling's trace and Pillai's trace for pot type (6.703) was larger than for soil type (1.459). In other words, the values of Hotelling's trace and Pillai's trace were closer for soil type than pot type. This indicates that the influence of pot type was more significant than soil type in the culture of this species. It was observed that pot type and soil type each has more influence on the final number of $L$. violaceus than the final weight. This is probably due to the fact that the offsprings had not yet matured into adults. The result might likely be different if the duration of the breeding experiment were extended beyond twelve weeks. With more time, the juveniles will grow and mature into adults and this will lead to a corresponding increase in weight.

It was observed that earthenware pot recorded a lower final mean earthworm number when compared with wooden pot. Earthenware pot was expected to provide a constant cool environment [20] for the worms by the principles of thermodynamics through the evaporation process. Reference [17] used earthenware pot to culture Eudrilus euginea in the laboratory under three (sandy, loamy, clayey) soil conditions, with and without cow dung, for a period of ten weeks. An impressive increase in earthworm number of between 170 and 1,395 percent was recorded for loamy soil. In this study however, the increase in earthenware pot was between 120 and 313 percent. The relatively low population growth in the earthenware pot in this study may be attributed to the fact that $L$. violaceus, being an ecological different earthworm species, does not probably require a continuously low temperature to achieve optimum population growth.

Loamy soil amended with $25 \%$ cow dung had the highest mean values across the board, followed by soil amended with $50 \%$ cow dung. The implications of these results for research are that a breeder of $L$. violaceus should prefer wooden pot and loamy soil amended with $25 \%$ cow dung for his breeding project.

When the final total number of earthworms produced in this research is compared with other works involving different species [14, 17, 19], L. violaceus may be considered a slow breeder in the laboratory. The relatively slow population growth recorded in this experiment may be attributed to the pattern of limited fecundity associated with endogeic species [21]. This challenge may be overcome probably by extending the duration of the breeding project 
or by encouraging in situ breeding in dedicated locations. The use of different soil amendments or different culture substrates may also encourage better reproductive and growth performance of this species.

\section{Conclusions}

The results obtained from this study indicate that if $L$. violaceus must be cultured ex situ, due consideration must be given to the choice of pot or container and the composition of the soil medium. This study, in our opinion, is the first to consider the effects of pot or container types on earthworm culture. Therefore, further studies on this and other species are needed to ascertain the degree of influence of pot or container types on earthworm breeding. The use of different soil amendments and different substrates for the culture of this species are also recommended.

\section{References}

[1] Owa, S. O., Dedeke, G. A., Moreyibi, O.H., Morafa, S. O. A., Senjobi, B. A. and Aladesida, A. A. 2010. Partitioning of Chemical effects of earthworms on growth performance of the vegetable Amaranthus. Australian Journal of Basic and Applied Sciences, 4 (8): 3755-3761.

[2] Sinha, R.K., Agarwal, S., Chauhan, K., Chandran, V., and Soni, B.K. 2010. Vermiculture technology: Reviving the dreams of Sir Charles Darwin for scientific use of earthworms in sustainable development programs. Technology and Investment, $1: 155-172$.

[3] Butt, K.R. 1999. Inculcation of earthworms into reclaimed soils: The U.K. experience. Journal of Land Degradation and Development, 10: 565-575.

[4] Organization for Economic Co-operation and Development (OECD). 1984. Earthworm acute toxicity tests. OECD Guidelines for Testing of Chemicals, 207.

[5] Spurgeon, D. J. and Hopkin, S. P. 2000. The development of genetically inherited resistance to zinc in laboratory selected generations of the earthworm Eisenia fetida. Environmental Pollution, 109: 193-201.

[6] Shin, K., Kim, J., and Kim, K. 2007. Earthworm toxicity test for the monitoring arsenic and heavy metal - containing mine tailings. Environmental Engineering Science, 24 (9) : $1257-1265$.

[7] Dada, E. O., Njoku, K. L., Osuntoki, A. A. and Akinola, M.O. 2013. Evaluation of the responses of a wetland, tropical earthworm to heavy metal contaminated soil. International Journal of Environmental Monitoring and Analysis, 1 (2): 47-52.

[8] Dynes, R. A. 2003. Earthworm technology for the rural industries research and development corporation. Australian Government Rural Industries Research and Development Corporation, no 03/085.
[9] Hemalatha, B. 2012. Recycling of industrial sludge along with municipal solid waste - vermicomposting method. International Journal of Advanced Engineering Technology, III (SII): 71-74.

[10] Balamurugan, M., Parthasarathi, K., Ranganthan, L.S. and Cooper, E. 2008. Hypothetical mode of action of earthworm extract with hepatoprotective and antioxidant properties. Journal of Zhejiang University Science 3, 9 (2): 141-147.

[11] Pan, R., Zhang, Z. and He, R. 2010. Earthworm protease. Applied and Environmental Soil Science, 2010(2010), ID 294258, $13 \mathrm{pp}$.

[12] Cooper, E.L., Balamurugan, M., Huang, C., Tsao, C.R., Heredia, J., Tommaseo-Ponzetta, M. and Paoletti, M.G. 2012. Earthworm dilong: Ancient, inexpensive, noncontroversial models may help clarify approaches to integrated medicine emphasizing neuroimmune systems. Evidence-Based Complementary and Alternative Medicine, 0212: 164152.

[13] Sogbesan, A.O., Ugwumba, A.A.A., Madu, C.T., Eze, S.S., and Isa, J. 2007. Culture and utilization of earthworm as animal protein supplement in the diet of Heterobranchus longifilis fingerlings. Journal of Fish and Aquatic Science. 2: 375-386.

[14] Sogbesan, O. A. and Ugwumba, A.A.A. 2006. Effect of different substrates on growth and productivity of Nigeria Semi-Arid Zone earthworm (Hyperiodrilus euryaulos, Clausen 1842) (Oligochaeta: Eudrilinae). World Journal of Zoology, 1(2): 103-112.

[15] Suthar, S. 2007. Influence of different food sources on growth and reproduction performance of compositing epigeics: Eudrilus eugeniae, Perionyx excavates, and Perionye sansibaricus. Applied Ecology and Environmental Research, 5(2): 79-92.

[16] Dedeke, G.A., Aladesida, A.A., and Akinola, O. A. 2009. Growth performance of Alma millsoni fed with brewers dried grain (BDG) and coconut husk. Journal of Cell and Animal Biology, 3 (5): 067-070.

[17] Ibrahim, B.U., Auta, J. and Adebote, D.A. 2010. Effects of soil types and enhanced nutrient levels on the productivity of earthworm (Eudrilus eugeniae, Kinberg). Bayero Journal of Pure and Applied Sciences, 3 (1): 59-62.

[18] Cholewa, J., Feeney, G.P., O'Reilly, M., Sturzenbaum, S.R., Morgan, A.J. and Plytycz, B. 2006. Auto fluorescence in eleocytes of some earthworm species. Folia Histochemica Et Cytobiologica, 44 (1): 65-71.

[19] Munnoli, P. M. and Bhosle, S. 2009. Effect of soil and cowdung proportion on vermin-compositing by deep burrower and surface feeder species. Journal of Scientific and Industrial Research, 68: 57-60.

[20] Kamaldeen, O. S., Uzoma, A., Olyemi, F. F. and Awagu, E. F. 2013. Effects of NSPRI tin-in-tin compared with pot-inpot evaporative cooler on the stored fruits. International Journal of Engineering and Technology, 2 (1): 63-69.

[21] Gajalakshmi, S. and Abbasi, S.A. 2004. Earthworms and Vermicomposting. Indian Journal of Biotechnology, 3: 486494. 